\title{
Silicon mitigates ammonium toxicity in yellow passionfruit seedlings
}

\author{
Gabriel B. da Silva Júnior ${ }^{*}$, Renato M. Prado ${ }^{2}$, Cid. N.S. Campos ${ }^{3}$, Flávia B. Agostinho ${ }^{4}$, \\ Sylvia L. O. Silva ${ }^{5}$, Luiz C.N. Santos ${ }^{2}$, and Leónides C. González ${ }^{6}$
}

'Universidade Federal do Piauí, Centro de Ciências Agrárias, Departamento de Fitotecnia, Campus Ministro Petrônio Portella, Ininga, CP: 64049-550, Teresina, Piauí, Brasil. "Corresponding author (gabrielbarbosa@ufpi.edu.br).

${ }^{2}$ Universidade Estadual Paulista "Julio de Mesquita Filho" Departamento de Solos e Adubos, Faculdade de Ciências Agrárias e Veterinárias, via de acesso Prof. Paulo Donato Castellane, CP: 14884-900, Jaboticabal, São Paulo, Brasil.

${ }^{3}$ Universidade Federal de Mato Grosso do Sul, Campus Chapadão do Sul, Rodovia MS-306, Zona Rural, CEP 79560-000, Chapadão do Sul, Mato Grosso do Sul, Brasil.

${ }^{4}$ Louisiana State University, School of Plant, Environmental Management and Soil Science, LSU AgCenter/CAPES, Câmpus Baton Rouge, Louisiana, USA.

${ }^{5}$ Instituto Federal do Maranhão, Estrada de Pacas, km-04, Enseada, CEP 65200-000, Pinheiro, Maranhão, Brasil.

${ }^{6}$ Universidad de Pamplona, Carretera de Bucaramanga km 1, Pamplona, Norte de Santander, Colombia.

Received: 30 October 2018; Accepted: 24 January 2019; doi:10.4067/S0718-58392019000300425

\begin{abstract}
Ammonium $\left(\mathrm{NH}_{4}^{+}\right)$toxicity in yellow passionfruit (Passiflora edulis Sims f. flavicarpa O. Deg.) may be mitigated by $\mathrm{Si}$ application. This study aimed to evaluate the interaction effect of $\mathrm{Si}$ and high level of $\mathrm{NH}_{4}{ }^{+}$on yellow passionfruit seedlings nutrition, physiology, growth, and DM production. Pots were filled with pinus bark and nutrition solution was applied. Treatments were arranged in a completely randomized design, with five replicates, in a $2 \times 2$ factorial scheme: two ratios of $\mathrm{NH}_{4}{ }^{+}$and nitrate, $\mathrm{NO}_{3}{ }^{+}\left(40 / 60 \%\right.$, without high level of $\mathrm{NH}_{4}{ }^{+}$; and $75 / 25 \%$, with high level of $\left.\mathrm{NH}_{4}{ }^{+}\right)$at $\mathrm{N}$ concentration of $13 \mathrm{mmol} \mathrm{N} \mathrm{L}^{-1}$, in the absence and presence of $\mathrm{Si}\left(2.0 \mathrm{mmol} \mathrm{L}^{-1}\right)$. Sixty days after seedling transplant it was evaluated: $\mathrm{N}, \mathrm{Si}, \mathrm{K}, \mathrm{Ca}$ and $\mathrm{Mg}$ root and shoots accumulation, leaf green color index (GCI), electrolyte leakage index $(\mathrm{ELI})$, intracellular $\mathrm{CO}_{2}$ concentration $\left(\mathrm{C}_{\mathrm{i}}\right)$, transpiration rate $\left(\mathrm{T}_{\mathrm{r}}\right)$, stomatal conductance $\left(\mathrm{g}_{\mathrm{s}}\right)$, net photosynthesis rate $\left(\mathrm{P}_{\mathrm{n}}\right)$, stem diameter, leaf area, root length, $\mathrm{N}$ use efficiency (NUE) and root and shoot DM content. Plants cultivated with Si had $19.1 \%$ and $16.3 \%$ lower $\mathrm{T}_{\mathrm{r}}$ and $\mathrm{g}_{\mathrm{s}}$, respectively, regardless $\mathrm{NH}_{4}{ }^{+}$concentration. Moreover, $\mathrm{C}_{\mathrm{i}}$ and $\mathrm{P}_{\mathrm{n}}$ were $13.2 \%$ and $16.4 \%$, respectively, higher in plants that received Si. Plants cultivated under high $\mathrm{NH}_{4}{ }^{+}$concentrations, with $\mathrm{Si}$ application had $17 \%$ bigger stem diameter and $15.4 \%$ bigger root length than plants without Si application. Si application in yellow passionfruit seedlings cultivated with high level of $\mathrm{NH}_{4}{ }^{+}$increased accumulation and NUE, root length, root DM, and GCI. In addition, Si application reduced ELI, which resulted in higher stem diameter. These results prove that $\mathrm{Si}$ application mitigates $\mathrm{NH}_{4}{ }^{+}$toxicity in yellow passionfruit seedlings.
\end{abstract}

Key words: Abiotic stress, beneficial element, $\mathrm{NH}_{4}{ }^{+}$, nitrogen, Passiflora edulis, toxicity.

\section{INTRODUCTION}

The $\mathrm{N}$ form taken up by plants affects its growth and development; hence, nitrate and ammonium proportions in nutrient solution is an important issue. Nitrogen supply through ammonium $\left(\mathrm{NH}_{4}{ }^{+}\right)$form requires lower energy consumption by the plants. Different from nitrate $\left(\mathrm{NO}_{3}{ }^{-}\right)$, ammonium is directly incorporated into the $\mathrm{C}$ chain without the need of an enzymatic reduction, which is energy dependent (Bittsánszky et al., 2015). However, it has been observed that $\mathrm{NH}_{4}^{+}$ supply in excess causes toxicity symptoms in most plant species (Li et al., 2013). 
Ammonium toxicity in plants is due to an increase in reactive oxygen species, as well as a decrease on cytoplasmic $\mathrm{pH}$, photosynthetic rate (Hu et al., 2015), and chlorophyll content, which affects membrane integrity (Kochanová et al., 2014). Moreover, high level of $\mathrm{NH}_{4}{ }^{+}$competes with other cations, such as $\mathrm{K}, \mathrm{Ca}$, and $\mathrm{Mg}$, during plant uptake process, reducing its accumulation; thus, plant DM production (Mendoza-Villarreal et al., 2015; Chen et al., 2016).

In order to mitigate ammonium toxic effect in plants, some management practices might be adopted, for example, the application of beneficial elements such as $\mathrm{Si}$. Although $\mathrm{Si}$ is not considered as a plant essential nutrient, it is responsible to protect plants against abiotic stresses (Kurdali et al., 2018), including drought, salinity, heat, cold, heavy metal toxicity (Liang et al., 2007), and nutrient imbalance, for example, ammonium toxicity (Prado et al., 2017).

Silicon beneficial effect in plants under stressed conditions is due to stimulation of plant antioxidant systems, which enhances membrane physical integrity (Kochanová et al., 2014; Barreto et al., 2018), to protect plant photosynthetic apparatus (Vaculíková et al., 2014), and to enhance nutrient uptake (Chen et al., 2016; Barreto et al., 2017; Kurdali et al., 2018; Mantovani et al., 2018). Therefore, Si enhances vegetative growth through this beneficial effect.

Silicon mitigating effect in plants under high level of ammonium has been studied in Brassica oleracea (Barreto et al., 2017), Zea mays (Campos et al., 2015), Solanum lycopersicum (Barreto et al., 2016), and Cucumis sativus (Campos et al., 2016). However, the role of $\mathrm{Si}$ in plant nutrition and in each organ of the plant is ambiguous. Moreover, there are lack of studies regarding $\mathrm{Si}$ and ammonium toxicity on seedlings of fruits, especially on seedlings of yellow passionfruit. Therefore, the hypothesis of this study is that ammonium toxicity in yellow passionfruit seedlings might be mitigated by application of Si through nutrient solution.

The objective of this study was to evaluate the interaction effect of Si and high level of ammonium on yellow passionfruit seedlings nutrition, physiology, growth, and DM production.

\section{MATERIALS AND METHODS}

\section{Experiment location and establishment}

The study was conducted between May and July 2014 at the greenhouse of São Paulo State University, campus Jaboticabal ( $21^{\circ} 15^{\prime} 22^{\prime \prime} \mathrm{S}, 48^{\circ} 18^{\prime} 58^{\prime \prime} \mathrm{W} ; 610 \mathrm{~m}$ a.s.l.), Brazil.

Yellow passionfruit (Hybrid BRS Rubi do Cerrado) seeds were sown in $53 \mathrm{~cm}^{3}$ pots filled with vermiculite. Pots were daily watered and seedlings (two pairs of fully formed leaves) were obtained $20 \mathrm{~d}$ after sowing. Yellow passionfruit seedlings were transferred to $1.7 \mathrm{~L}$ polypropylene pots filled with sterilized pine bark (grain size: $6.0 \mathrm{~mm}$, density: 275.9 $\mathrm{kg} \mathrm{m}^{-3}$, and water retention capacity: $1.32 \mathrm{~kg} \mathrm{~kg}^{-1}$ ) in which the experiment was established.

The treatments ( $\mathrm{N}$ source and $\mathrm{Si}$ application) were arranged in a completely randomized design, with five replicate, in a $2 \times 2$ factorial scheme: two ratios of $\mathrm{NH}_{4}{ }^{+}$and $\mathrm{NO}_{3}{ }^{-}\left(40 / 60 \%\right.$, low level $\mathrm{NH}_{4}{ }^{+}\left[5.2 \mathrm{mmol} \mathrm{L}^{-1} \mathrm{NH}_{4}{ }^{+}\right.$; and $75 / 25 \%$, with high level of $\mathrm{NH}_{4}^{+}\left[9.75 \mathrm{mmol} \mathrm{L}^{-1} \mathrm{NH}_{4}^{+}\right]$), in the presence or absence of $\mathrm{Si}$ at $2.0 \mathrm{mmol} \mathrm{L}{ }^{-1}$. Nitrogen was applied at $13 \mathrm{mmol} \mathrm{L}^{-1}$ and ammonium and nitrate ratios were determined based on previous experiment. Each experimental unit consisted of four individually grown seedlings in a polypropylene pot with a $1.7 \mathrm{~L}$ volume (diameter: $12 \mathrm{~cm}$; bottom diameter: $10 \mathrm{~cm}$; height: $20 \mathrm{~cm}$ ).

\section{Seedlings growth conditions}

Yellow passionfruit seedlings were grown in a Hoagland and Arnon (1950) nutrient solution modified according to N and $\mathrm{Si}$ treatments, and with Fe-ethylendiamine di(2-hydroxy-4-methylphenylacetic) acid (EDDHMA) as Fe source (Table 1). The sources of $\mathrm{NH}_{4}{ }^{+}$and $\mathrm{NO}_{3}{ }^{-}$were $\mathrm{NH}_{4} \mathrm{Cl}(\mathrm{N}=26.4 \%)$ and $\mathrm{Ca}\left(\mathrm{NO}_{3}\right)_{2} \cdot 5 \mathrm{H}_{2} \mathrm{O}(\mathrm{N}=11.1 \%)$, respectively,

Table 1. Nutrient solution content modified according to $\mathrm{NH}_{4}{ }^{+}$and $\mathrm{NO}_{3}$ ratios and $\mathrm{Si}$ treatments.

\begin{tabular}{ccccccccc}
\hline $\mathrm{NH}_{4}{ }^{+} / \mathrm{NO}_{3}{ }^{-}$ & $\mathrm{Si}$ & $\mathrm{NH}_{4}{ }^{+}$ & $\mathrm{NO}_{3}{ }^{-}$ & $\mathrm{P}$ & $\mathrm{K}$ & $\mathrm{Ca}$ & $\mathrm{Mg}$ & $\mathrm{S}$ \\
\cline { 2 - 9 }$(\%)$ & & & & & $\mathrm{mmol} \mathrm{L}^{-1}$ & & & \\
$40 / 60$ & 0.0 & 5.2 & 7.8 & 1.0 & 6.0 & 7.8 & 2.0 & 2.0 \\
$40 / 60$ & 2.0 & 5.2 & 7.8 & 1.0 & 6.0 & 7.8 & 2.0 & 2.0 \\
$75 / 25$ & 0.0 & 9.8 & 3.2 & 1.0 & 6.0 & 7.8 & 2.0 & 2.0 \\
$75 / 25$ & 2.0 & 9.8 & 3.2 & 1.0 & 6.0 & 7.8 & 2.0 & 2.0 \\
\hline
\end{tabular}


whereas monosilicic acid $\left(\mathrm{Si}=28.5 \mathrm{~g} \mathrm{~L}^{-1}\right)$ was used as $\mathrm{Si}$ source. Treatments were balanced for Ca concentration using $\mathrm{CaCl}_{2} \cdot 2 \mathrm{H}_{2} \mathrm{O}$. Further macronutrients fertilization was done using $\mathrm{KH}_{2} \mathrm{PO}_{4}, \mathrm{KCl}$ and $\mathrm{MgSO}_{4} \cdot 7 \mathrm{H}_{2} \mathrm{O}$. Micronutrients were provided through Hoagland and Arnon (1950) solution which contained: $2.86 \mathrm{~g} \mathrm{H}_{3} \mathrm{BO}_{3} \mathrm{~L}^{-1} ; 1.81 \mathrm{~g} \mathrm{MnCl}_{2} \cdot 4 \mathrm{H}_{2} \mathrm{O} \mathrm{L}^{-1} ; 0.10 \mathrm{~g}$

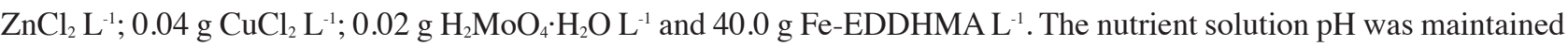
at $6.0 \pm 0.1$.

Nutrient solutions adjusted according to the treatments (Table 1) were daily applied to the pots at $50 \mathrm{~mL}$ until $20 \mathrm{~d}$ after transplanting (DAT). From 21 to 35 DAT $100 \mathrm{~mL}$ solution were applied, whereas from 36 to 60 DAT the solution was applied at $150 \mathrm{~mL}$. Polypropylene plates $(150 \mathrm{~mL})$ were placed at the base of each pot in order to collect the nutrient solution. The nutrient solution was manually returned to the pots at the end of each day. Application volumes were determined based on the plant development observed in previous experiments.

A digital thermo-hygrometer (thermo-hygrometer Instrutherm, HT-210, São Paulo; São Paulo State, Brazil) were used to collect daily air temperature and relative humidity at the greenhouse. Data were collected between August and September of 2014, from seedlings transplant to plant harvest (Figure 1).

\section{Photosynthetic parameters}

At 60 DAT, intracellular $\mathrm{CO}_{2}$ concentration $\left(\mathrm{C}_{\mathrm{i}} ; \mu \mathrm{mol} \mathrm{mol}^{-1}\right)$, transpiration rate $\left(\mathrm{T}_{\mathrm{r}} ; \mathrm{mmol} \mathrm{m}^{-2} \mathrm{~s}^{-1}\right)$, stomatal conductance $\left(\mathrm{g}_{\mathrm{s}}\right.$;

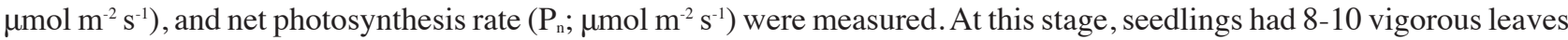
and the first visible tendril. Evaluations were performed at the fourth fully developed leaf from the apex to the bottom, as indicated by Malavolta et al. (1997) as the diagnosis leaf of yellow passionfruit seedlings. Data were collected from two plants per pot, between 08:00 and 10:00 h, under $\mathrm{CO}_{2}$ ambient concentration $\left(372 \pm 10 \mathrm{~mol} \mathrm{~m}^{-2} \mathrm{~s}^{-1}\right)$, and photosynthetically active photon flux of $1200 \mathrm{~mol} \mathrm{~m}^{-2} \mathrm{~s}^{-1}$. An infrared gas analyzer (LI-6400; LI-COR, Lincoln, Nebraska, USA) was used.

\section{Leaf green color and electrolyte leakage indexes}

Leaf green color index was measured using a portable chlorophyll meter (CCM-200; Opti-Sciences, Hudson, New Hampshire, USA). The readings were taken between 11:00 and 12:00 $\mathrm{h}$ at the upper, middle and lower part of the leaves. Moreover, membrane physical integrity of leaf cells was determined based on the electrolyte leakage index. A conductivity meter was used (CD 880; Instrutherm, São Paulo, São Paulo State, Brazil) as suggested by Dionisio-Sese and Tobita (1998). Data were collected from $5 \mathrm{~mm}$-cuts of fresh leaves weighting $100 \mathrm{mg}$ each.

\section{Plant parameters and nutritional composition}

At 60 DAT, the stem diameter $(\mathrm{mm})$ was measured $2.0 \mathrm{~cm}$ from the base of the plant, using a digital caliper (727-2001; Starrett, Athol, Massachusetts, USA), whereas leaf area $\left(\mathrm{cm}^{2}\right)$ was obtained through the sum of all leaves area taken in each plant using a digital meter (model L1-3000; LI-COR, Lincoln, Nebraska, USA). Root length (cm) was also measured.

Plants were harvest, washed, and separated into shoots and roots before drying it in air forced oven at $65 \pm 2{ }^{\circ} \mathrm{C}$. Roots and shoots dry weight were determined.

Figure 1. Air temperature (a) and relative air humidity (b) at the greenhouse during experiment.
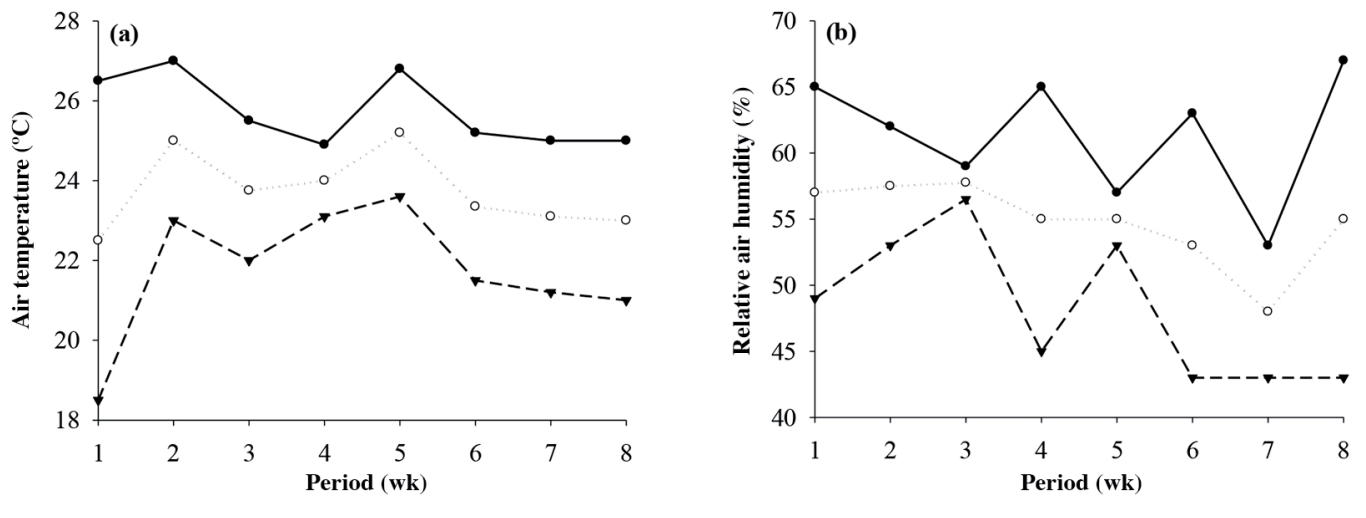

$\rightarrow$ Maximum $\quad 0$ Average $\quad \rightarrow-$ Minimum 
After drying, plants were ground in a Wiley mill (Thomas Scientific, Swedesboro, New Jersey, USA) and N, K, Ca and $\mathrm{Mg}$ contents determined according to Bataglia et al. (1983) methodology. $\mathrm{N}$ content was determined by the Kjeldahl method. For the $\mathrm{K}, \mathrm{Ca}$ and $\mathrm{Mg}$ content, $0.2 \mathrm{~g}$ dried samples were added in $5 \mathrm{~mL}$ perchloric acid and $15 \mathrm{~mL}$ nitric acid and incubated overnight at room temperature, then digested at $180{ }^{\circ} \mathrm{C}$ using a heating block, and diluted to a volume of $50 \mathrm{~mL}$ with distilled demonized water. The concentrations of $\mathrm{K}, \mathrm{Ca}$, and $\mathrm{Mg}$, was determined by atomic absorption spectrometer (SpectrAA220FS, Varian, Palo Alto, California, USA). Silicon content was determined according to Kraska and Breitenbeck (2010) procedure. The Si contents of rice leaves were determined by the colorimetric molybdenum blue method. In brief, $0.3 \mathrm{~g}$ samples of yellow passionfruit leaves were ashed in porcelain crucibles for $3 \mathrm{~h}$ at $550{ }^{\circ} \mathrm{C}$, the ash was dissolved in $1.3 \%$ hydrogen fluoride, then the Si concentrations in the solutions were measured by the colorimetric molybdenum blue method at $811 \mathrm{~nm}$ with a spectrophotometer (V-M5, Bel Engineering, Monza, Italy). Based on nutrient content and plant DM, root and shoot nutrient accumulation was calculated. The $\mathrm{N}$ use efficiency (NUE, $\mathrm{g} \mathrm{g}^{-1}$ ) was also calculated from root and shoot $\mathrm{N}$ accumulation through Fageria (1998) formula: NUE = (Root or shoot DM mass)/Root or shoot $\mathrm{N}$ accumulation.

\section{Statistical analysis}

The data were analyzed through ANOVA based on $\mathrm{F}$ test. Mean comparison of $\mathrm{NH}_{4}{ }^{+}$and $\mathrm{NO}_{3}$ ratios and $\mathrm{Si}$ treatment were also done using Tukey's test $(\mathrm{P} \leq 0.05)$. A Pearson correlation analysis $(\mathrm{P} \leq 0.05)$ was conducted among variables. The software SisVar was used for all statistical analysis (Ferreira, 2011).

\section{RESULTS AND DISCUSSION}

\section{Plant physiological parameters}

The ANOVA of $\mathrm{NH}_{4}{ }^{+}$and $\mathrm{NO}_{3}{ }^{-}$ratios and $\mathrm{Si}$ application are presented in Table 2. It was observed a significant interaction effect between $\mathrm{NH}_{4}{ }^{+}$and $\mathrm{NO}_{3}{ }^{-}$ratios and $\mathrm{Si}$ on green color and electrolyte leakage indexes $(\mathrm{P} \leq 0.05)$ (Table 2). Under high concentration of ammonium, plants applied with $\mathrm{Si}$ had $44.1 \%$ higher leaf green color index than plants without $\mathrm{Si}$ application (Figure 2a). However, in the presence of Si, there was no increase in the leaf green color index in plants grown in nutrient solution with low ammonium concentration. Unlike in systems containing low $\mathrm{NH}_{4}{ }^{+}$concentration, Si uptake is enhanced in plants under high ammonium or in stressed conditions, which is elucidated by a positive correlation between Si accumulation and leaf green color index $\left(\mathrm{r}=0.80^{* *}\right)$.

Similar results were observed by authors that studied $\mathrm{Si}$ and $\mathrm{NH}_{4}{ }^{+}$toxicity interaction in other plants (Hu et al., 2015; Campos et al., 2016; Barreto et al., 2017). The toxic effect of $\mathrm{NH}_{4}{ }^{+}$is possibly due to increased content of reactive oxygen species $\left(\mathrm{O}_{2}^{-}\right.$and $\left.\mathrm{H}_{2} \mathrm{O}_{2}\right)$ in plants under high concentration of $\mathrm{NH}_{4}{ }^{+}$, which may cause oxidative peroxidation and reduce leaf chlorophyll content (Prado et al., 2017; Barreto et al., 2018). Moreover, chlorosis and necrosis in older leaves of yellow

Table 2. ANOVA of leaf green color index (GCI), electrolyte leakage index (ELI), intracellular $\mathrm{CO}_{2}$ concentration $\left(C_{i}\right)$ transpiration rate $\left(T_{r}\right)$, stomatal conductance $\left(g_{s}\right)$, and net photosynthesis rate $\left(P_{n}\right)$ of yellow passionfruit seedlings under different $\mathrm{NH}_{4}{ }^{+}$and $\mathrm{NO}_{3}{ }^{-}$ratios with and without $\mathrm{Si}$ application.

\begin{tabular}{|c|c|c|c|c|c|c|}
\hline Treatment & GCI & ELI & $\mathrm{C}_{\mathrm{i}}$ & $\mathrm{T}_{\mathrm{r}}$ & $\mathrm{g}_{\mathrm{s}}$ & $P_{n}$ \\
\hline & \multicolumn{2}{|c|}{$\%$} & $\mu \mathrm{mol} \mathrm{mol}{ }^{-1}$ & $\mathrm{mmol} \mathrm{m} \mathrm{m}^{-2} \mathrm{~s}^{-1}$ & \multicolumn{2}{|c|}{$-\mu \mathrm{mol} \mathrm{m} \mathrm{m}^{-2} \mathrm{~s}^{-1}$} \\
\hline $\mathrm{NH}_{4}^{+} / \mathrm{NO}_{3}^{-}(\mathrm{R})$ & $24.6^{*}$ & $124.7^{*}$ & $3.0^{\mathrm{ns}}$ & $7.4^{* *}$ & $1.9^{\mathrm{ns}}$ & $0.9^{\text {ns }}$ \\
\hline $40 / 60$ & 40.6 & 23.1 & 182.9 & 4.0 & 0.092 & 9.8 \\
\hline $75 / 25$ & 27.5 & 38.9 & 171.3 & 4.6 & 0.098 & 9.3 \\
\hline LSD & 5.6 & 3.0 & - & 0.2 & - & - \\
\hline Silicon $(\mathrm{Si})$ & $14.9^{* *}$ & $41.9^{* *}$ & $14.4^{* *}$ & $48.3^{* *}$ & $17.0^{* *}$ & $4.0^{*}$ \\
\hline Absence & 29.0 & 35.6 & 164.4 & 4.2 & 0.104 & 9.2 \\
\hline Presence & 39.1 & 26.4 & 189.4 & 3.4 & 0.087 & 11.0 \\
\hline LSD & 5.6 & 3.0 & 14.2 & 0.2 & 0.008 & 1.3 \\
\hline $\mathrm{R} \times \mathrm{Si}$ & $7.1^{*}$ & $7.1^{*}$ & $4.4^{\mathrm{ns}}$ & $1.1^{\mathrm{ns}}$ & $0.2^{\mathrm{ns}}$ & $1.8^{\mathrm{ns}}$ \\
\hline $\mathrm{CV}, \%$ & 10.3 & 10.2 & 8.5 & 6.5 & 9.8 & 14.6 \\
\hline
\end{tabular}

LSD: Least significant difference; CV: coefficient of variation; " ns: nonsignificant.

", "Significant at the 0.05 and 0.01 probability levels, respectively, according to F test. 
Figure 2. Leaf green color index (a) and electrolyte leakage index (b) of yellow passionfruit seedlings under different $\mathrm{NH}_{4}{ }^{+}$ and $\mathrm{NO}_{3}$ ratios with or without $\mathrm{Si}$ application.
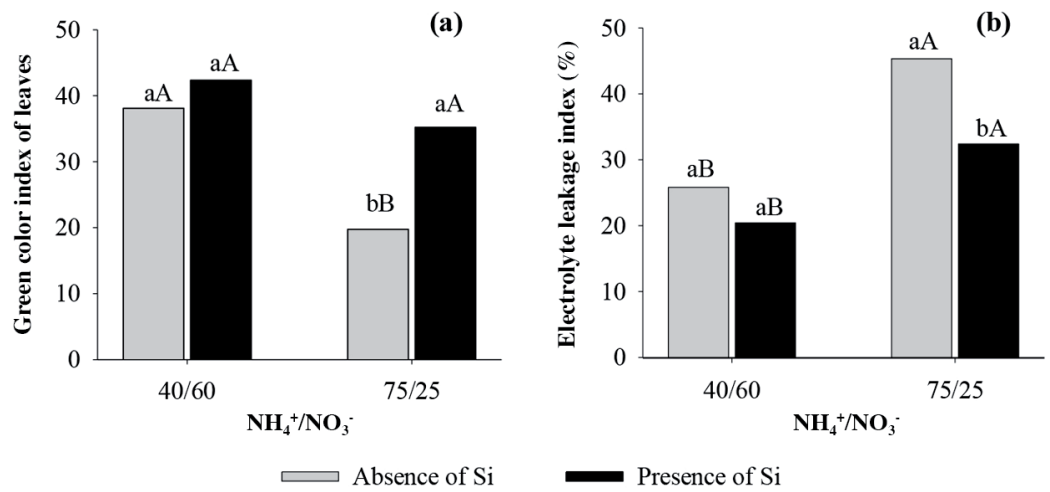

Means followed by different lower-case letters indicate Si significant effect within $\mathrm{NH}_{4}{ }^{+}$and $\mathrm{NO}_{3}{ }^{-}$ratios and uppercase letters indicate $\mathrm{NH}_{4}{ }^{+}$and $\mathrm{NO}_{3}$ ratios significant effect within $\mathrm{Si}$ concentrations, according to Tukey's test $(\mathrm{P} \leq 0.05)$.

passionfruit seedlings indicated a nutritional plant disorder under $\mathrm{NH}_{4}{ }^{+}$toxicity. These symptoms were also reported by Campos et al. (2016) and Barreto et al. (2018) in Cucumis sativus and Solanum lycopersicum, respectively, grown in nutrient solution containing high concentration of $\mathrm{NH}_{4}{ }^{+}$.

The electrolyte leakage index of yellow passionfruit leaves increased at high concentration of $\mathrm{NH}_{4}^{+}$, regardless $\mathrm{Si}$ application $(\mathrm{P} \leq 0.05)$ (Figure $2 \mathrm{~b}$ ). This resulted from the membrane damage and cell wall breakage, which increase cell electrolyte leakage (Kochanová et al., 2014). Similar effect was observed in plants of Arabidopsis thaliana (Helali et al., 2010), Brassica oleracea (Barreto et al., 2017), and S. lycopersicum (Barreto et al., 2018) cultivated under high $\mathrm{NH}_{4}{ }^{+}$concentrations. In contrast, plants under high $\mathrm{NH}_{4}{ }^{+}$concentration that received Si fertilization had lower electrolyte leakage index than plants without $\mathrm{Si}$ (Figure 2b). This might be explained by plant enhanced uptake of $\mathrm{Si}$ and $\mathrm{Ca}$, as showed through the negative correlation between electrolyte leakage index and $\mathrm{Si}\left(\mathrm{r}=-0.71^{* *}\right)$ and electrolyte leakage index and $\mathrm{Ca}\left(\mathrm{r}=-0.71^{* *}\right)$. Silicon increases membranes physical integrity of plants under different abiotic stress, as noticed by Kochanová et al. (2014) in Zea mays and Li et al. (2012) in Cucumis melo. Moreover, Si connects to free monophenols, which forms a Si-phenol compound that acts avoiding accumulation of reactive oxygen species in the cell (Maksimovic et al., 2007), and reduces lipid peroxidation, which preserve cell chloroplasts and organic compounds (Hernandez-Apaolaza, 2014; Kochanová et al., 2014). In addition, Ca is an essential nutrient responsible for cell membrane integrity (Kochanová et al., 2014), which also contributes to plant lower electrolyte leakage index.

Yellow passionfruit seedlings leaf transpiration $\left(\mathrm{T}_{\mathrm{r}}\right)$ was $13.1 \%$ higher in plants under high concentration of $\mathrm{NH}_{4}{ }^{+}$than in plants under low concentration $(\mathrm{P} \leq 0.01)$ (Table 2). High concentration of $\mathrm{NH}_{4}{ }^{+}$might decrease intracellular $\mathrm{pH}$ and cause an osmotic imbalance, which increase reactive oxygen concentration. Under oxidative stress, plants may modify its physiological activities, such as transpiration rate (Bittsánszky et al., 2015). In contrast, plants applied with Si had 19.1\% and $16.3 \%$ lower $\mathrm{T}_{\mathrm{r}}$ and $\mathrm{g}_{\mathrm{s}}$, respectively, regardless $\mathrm{NH}_{4}{ }^{+}$concentration. Moreover, $\mathrm{C}_{\mathrm{i}}$ and $\mathrm{P}_{\mathrm{n}}$ were $13.2 \%(\mathrm{P} \leq 0.01)$ and $16.4 \%$ ( $\mathrm{P} \leq 0.01)$, respectively, higher in plants that received $\mathrm{Si}$ (Table 2). Silicon benefits plant physiological activities, especially photosynthesis, due to its deposition on the abaxial leaf surface. This deposition help plant maintain its leaves erect, which increase light interception (Feng et al., 2010), and active photosynthetic area (Kurdali et al., 2013). Silicon deposition beneath leaf epidermis forms a double-layer that affects $\mathrm{g}_{s}$ and intracellular $\mathrm{CO}_{2}$ concentration; thus affecting photosynthetic efficiency (Kochanová et al., 2014). Higher photosynthetic efficiency and growth were reported in Cicer arietinum (Kurdali et al., 2013), and Z. mays (Vaculíková et al., 2014) plants cultivated in a system containing Si.

\section{Plant N, Si, K, Ca, and Mg accumulation}

There was a significant interaction between $\mathrm{NH}_{4}{ }^{+} / \mathrm{NO}_{3}$ and $\mathrm{Si}$ application on $\mathrm{N}(\mathrm{P} \leq 0.05)$ and $\mathrm{Si}(\mathrm{P} \leq 0.05)$ root accumulation (Table 3). Nitrogen and Si root accumulation decreased by $21.9 \%$ and $45.4 \%$, respectively, in yellow passionfruit seedlings grown under high $\mathrm{NH}_{4}{ }^{+} / \mathrm{NO}_{3}{ }^{-}$compared to plants under low $\mathrm{NH}_{4}{ }^{+} / \mathrm{NO}_{3}{ }^{-}$, regardless Si application (Table 3). In contrast, an increase on root $\mathrm{N}$ and $\mathrm{Si}$ accumulation by $13.4 \%$ and $20.0 \%$, respectively, was observed in plants applied with $\mathrm{Si}$, 
Table 3. ANOVA of N, Si, K, Ca, and Mg root and shoot accumulation in yellow passionfruit seedlings under different $\mathrm{NH}_{4}^{+}$and $\mathrm{NO}_{3}^{-}$ratios with and without $\mathrm{Si}$ application.

\begin{tabular}{|c|c|c|c|c|c|c|c|c|c|c|}
\hline \multirow[b]{2}{*}{ Treatments } & \multicolumn{2}{|c|}{$\mathrm{N}$} & \multicolumn{2}{|c|}{$\mathrm{Si}$} & \multicolumn{2}{|c|}{ K } & \multicolumn{2}{|c|}{$\mathrm{Ca}$} & \multicolumn{2}{|c|}{$\mathrm{Mg}$} \\
\hline & Root & Shoot & Root & Shoot & Root & Shoot & Root & Shoot & Root & Shoot \\
\hline & & & & & $\mathrm{mg} \mathrm{pl}$ & ant $^{-1}$ & & & & 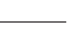 \\
\hline $\mathrm{NH}_{4}{ }^{+} / \mathrm{NO}_{3} \cdot(\mathrm{R})$ & $41.1^{* *}$ & $23.5^{* *}$ & $99.6^{* *}$ & $0.2^{\mathrm{ns}}$ & $23.7^{* *}$ & $9.1^{* *}$ & $29.8^{* *}$ & $23.2^{* *}$ & $17.4^{* *}$ & $14.7^{7 *}$ \\
\hline $40 / 60$ & 37.4 & 270.9 & 1.1 & 0.8 & 35.5 & 201.9 & 10.7 & 168.3 & 4.4 & 30.7 \\
\hline $75 / 25$ & 29.2 & 215.9 & 0.6 & 0.7 & 25.8 & 173.3 & 6.6 & 114.8 & 3.5 & 23.0 \\
\hline LSD & 2.7 & 24.1 & 0.2 & - & 4.2 & 20.1 & 1.6 & 7.9 & 0.4 & 4.3 \\
\hline Silicon $(\mathrm{Si})$ & $.2^{* *}$ & $20.5^{* *}$ & $6.9^{*}$ & 26. & $2.1^{\mathrm{ns}}$ & $23.4^{* *}$ & $1.8^{\mathrm{ns}}$ & $20.8^{* *}$ & $2.9^{\text {ns }}$ & $19.8^{* *}$ \\
\hline be & 2 & 217 & 0.8 & & 29.2 & & 8.1 & 116.3 & 3.8 & 22.4 \\
\hline Presence & 35.3 & 269.1 & 1.0 & 0.9 & 32.1 & 210.5 & 9.1 & 166.8 & 4.1 & 31.3 \\
\hline $\mathrm{SD}$ & 2.7 & 24.1 & 0.1 & 0.2 & - & 20.1 & - & 7.9 & - & 4.3 \\
\hline $\mathrm{R} \times \mathrm{Si}$ & $17.1^{*}$ & $0.1^{\text {ns }}$ & $7.3^{*}$ & $1.6^{\mathrm{ns}}$ & $0.1^{\mathrm{n}}$ & $0.1^{\mathrm{ns}}$ & $0.2^{\mathrm{ns}}$ & $1.5^{\text {ns }}$ & $1.5^{\mathrm{ns}}$ & $0.8^{\text {ns }}$ \\
\hline $\mathrm{CV}, \%$ & 8.6 & 10.4 & 10.4 & 13.8 & 14.6 & 11.3 & 19.3 & 17.5 & 11.8 & 16.8 \\
\hline
\end{tabular}

LSD: Least significant difference; CV: coefficient of variation; ${ }^{n}$ : nonsignificant.

${ }^{*},{ }^{*}$ Significant at the 0.05 and 0.01 probability levels, respectively, according to $\mathrm{F}$ test.

regardless $\mathrm{NH}_{4}^{+} / \mathrm{NO}_{3}^{-}$(Figures $3 \mathrm{a}$ and b). The reduction in $\mathrm{N}$ root accumulation in plants grown under high ammoniacal $\mathrm{N}$ might have resulted from the toxic effect of $\mathrm{NH}_{4}{ }^{+}$in plants, which causes damaging in the root system and reduction in nutrient uptake (Li et al., 2014). Silicon content in plants applied with $\mathrm{Si}$ was significantly higher than in plants without $\mathrm{Si}$ application, regardless $\mathrm{NH}_{4}{ }^{+}$concentration (Figure $3 \mathrm{~b}$ ). This demonstrates that yellow passionfruit is capable of taking up $\mathrm{Si}$ from nutrition solution and further accumulate it in its cells. The beneficial effect of $\mathrm{Si}$ is attributed to its deposition on plant root and shoots tissue as $\mathrm{SiO}_{2}$, which enhances plant strength and act as a physical barrier against biotic and abiotic stresses (Ma and Yamaji, 2015). Plants that accumulates high concentration of Si in their cells are more prone to resist abiotic stresses, such as ammoniacal toxicity, than plant that do not accumulate Si in their cells (Ma and Yamaji, 2015).

Shoot $\mathrm{N}$ accumulation was significantly affected by $\mathrm{NH}_{4}{ }^{+} / \mathrm{NO}_{3}$, as well as root and shoot $\mathrm{K}, \mathrm{Ca}$ and $\mathrm{Mg}$ accumulation. Significant effect of Si application was also observed on N, Si, K, Ca and $\mathrm{Mg}$ shoot accumulation (Table 3). Root and shoot accumulation of $\mathrm{K}, \mathrm{Ca}$ and $\mathrm{Mg}$ were lower in plants under high $\mathrm{NH}_{4}{ }^{+}$concentration than in plants grown under low $\mathrm{NH}_{4}{ }^{+}$concentration (Table 3). The reduction in accumulation of these cations in plants grown under high ammoniacal $\mathrm{N}$ was also observed by others author in Fragaria spp. (Choi et al., 2011), Eustoma grandiflorum (Mendoza-Villarreal et al., 2015), Sorghum bicolor (Chen et al., 2016), and B. oleracea (Barreto et al., 2017). The nutrient imbalance observed in the ammoniacal system is due to the antagonism effect between $\mathrm{NH}_{4}{ }^{+}$and the other cations, as they compete for the same

Figure 3. Nitrogen (a) and $\mathrm{Si}$ (b) root accumulation in yellow passionfruit seedlings under different $\mathrm{NH}_{4}{ }^{+}$and $\mathrm{NO}_{3}{ }^{-}$ratios with or without $\mathrm{Si}$ application.
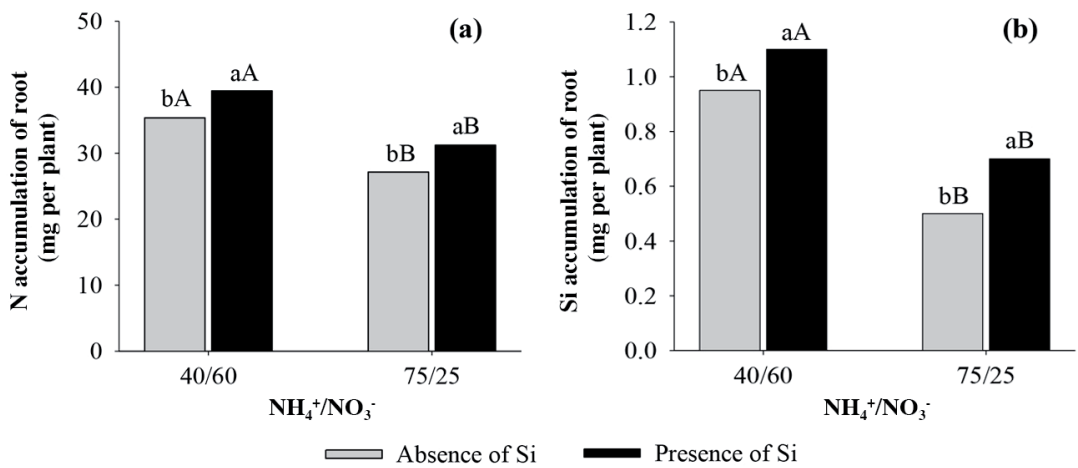

Means followed by different lower-case letters indicate $\mathrm{Si}$ significant effect within $\mathrm{NH}_{4}{ }^{+}$and $\mathrm{NO}_{3}$ ratios and uppercase letters indicate $\mathrm{NH}_{4}^{+}$and $\mathrm{NO}_{3}^{-}$ratios significant effect within $\mathrm{Si}$ concentrations, according to Tukey's test $(\mathrm{P} \leq 0.05)$. 
uptake site in the roots (Marschner, 2012). In addition, there is an enhancement of $\mathrm{NH}_{4}{ }^{+}$influx in the plasma membrane, which increase other cations efflux with further extrusion of these cations into the cell vacuole; thus, a deficiency symptoms expression in the plant (Mendoza-Villarreal et al., 2015).

Yellow passionfruit seedlings grown in the presence of the beneficial element showed higher $\mathrm{K}, \mathrm{Ca}$ and $\mathrm{Mg}$ shoot accumulation than plants cultivated without $\mathrm{Si}$ application, regardless $\mathrm{NH}_{4}{ }^{+}$concentration (Table 3). The beneficial effect of Si on cations uptake might vary according to plant species and stress conditions (Chen et al., 2016). Barreto et al. (2017) observed that $\mathrm{Si}$ increased $\mathrm{K}, \mathrm{Ca}$ and $\mathrm{Mg}$ foliar content of brassicas cultivated in nutrient solution containing or not high ammoniacal $\mathrm{N}$. Silicon stimulates $\mathrm{H}^{+}$-ATPase activity in cell membrane, which might explain its effect on $\mathrm{K}$ uptake (Liang, 1999). Moreover, Si reduces the concentration of reactive oxygen species in the plant, such as $\mathrm{O}_{2}^{-}$and $\mathrm{H}_{2} \mathrm{O}_{2}$, which mitigates foliar chlorosis and necrosis symptoms resulted from $\mathrm{K}$ deficiency (Chen et al., 2016). The mechanisms by which $\mathrm{Si}$ increases $\mathrm{Ca}$ and $\mathrm{Mg}$ uptake is still being studied.

\section{Plant growth, $\mathrm{N}$ use efficiency and dry matter}

A significant interaction effect between $\mathrm{NH}_{4}{ }^{+} / \mathrm{NO}_{3}{ }^{-}$and $\mathrm{Si}$ was observed on stem diameter, root length, NUE and root DM. Stem diameter and root length of plants cultivated under high $\mathrm{NH}_{4}{ }^{+} / \mathrm{NO}_{3}{ }^{-}$without $\mathrm{Si}$ were lower than in plants cultivated under low $\mathrm{NH}_{4}{ }^{+} / \mathrm{NO}_{3}$ (Table 4). Similar effect of $\mathrm{NH}_{4}{ }^{+}$toxicity on plant growth was observed in E. grandiflorum (Mendoza-Villarreal et al., 2015), C. sativus (Campos et al., 2016) and S. lycopersicum (Barreto et al., 2016; 2018). In contrast, plants cultivated under high $\mathrm{NH}_{4}{ }^{+} / \mathrm{NO}_{3}{ }^{-}$with $\mathrm{Si}$ application had $17 \%$ bigger stem diameter (Figure 4a) and $15.4 \%$ bigger root length (Figure 4b) than plants without Si application. Silicon application increased root $\mathrm{N}$ accumulation (Figure 3a) and leaf green color index (Figure 2a) of plants under ammoniacal stress, which might explain the better development of this plant parts. Moreover, plants were under lower stress as indicated by lower plant electrolyte leakage index (Figure 2b). The improvement on root system were also observed in Z. mays, grown in nutrient solution containing $\mathrm{Si}$ and high concentration of $\mathrm{NaCl}$ (Kochanová et al., 2014), and in S. lycopersicum (Barreto et al., 2016), and B. oleracea (Barreto et al., 2017) grown in nutrient solution with Si and high ammonium concentration. These results elucidate the beneficial effect of this element when plants are under abiotic stresses. It is noteworthy that in high concentrations of ammonium, Si promoted greater NUE, resulting in better use of nitrogen to increase stem diameter and root DM. In this case, no toxic effect of $\mathrm{NH}_{4}{ }^{+}$was observed, even at high concentrations, probably due to the $\mathrm{Si}$ mitigating effect.

Individual effect of $\mathrm{NH}_{4}{ }^{+} / \mathrm{NO}_{3}$ and $\mathrm{Si}$ was also observed on leaf area, $\mathrm{NUE}$ and shoot DM (Table 4). Regardless $\mathrm{Si}$ application, high $\mathrm{NH}_{4}{ }^{+} / \mathrm{NO}_{3}$ reduced leaf area of yellow passionfruit seedlings by $27.1 \%$ compared to low $\mathrm{NH}_{4}{ }^{+} / \mathrm{NO}_{3}$ (Table 4). The effect of high $\mathrm{NH}_{4}{ }^{+} \mathrm{NO}_{3}$ on leaf area is due to $\mathrm{NH}_{4}{ }^{+}$toxicity in yellow passionfruit seedlings, which reduces $\mathrm{N}$ accumulation (Table 2); hence, limits leaf expansion.

Table 4. ANOVA of plant height, stem diameter, leaf area, root length, and root and shoot nitrogen use efficiency (NUE) and dry matter of yellow passionfruit seedlings under different $\mathrm{NH}_{4}{ }^{+}$and $\mathrm{NO}_{3}$ ratios with and without $\mathrm{Si}$ application.

\begin{tabular}{|c|c|c|c|c|c|c|c|}
\hline \multirow[b]{2}{*}{ Treatment } & \multirow{2}{*}{$\begin{array}{c}\text { Stem } \\
\text { diameter }\end{array}$} & \multirow{2}{*}{$\begin{array}{c}\text { Leaf } \\
\text { area }\end{array}$} & \multirow{2}{*}{$\begin{array}{l}\text { Root } \\
\text { length }\end{array}$} & \multicolumn{2}{|c|}{ NUE } & \multicolumn{2}{|c|}{ Dry matter } \\
\hline & & & & Root & Shoot & Root & Shoot \\
\hline & $\mathrm{mm}$ & $\mathrm{cm}^{2}$ & $\mathrm{~cm}$ & \multicolumn{2}{|c|}{$-\mathrm{g} \mathrm{g}^{-1}$} & \multicolumn{2}{|c|}{ - g plant t $^{-1}$} \\
\hline $\mathrm{NH}_{4}^{+} / \mathrm{NO}_{3}^{-}(\mathrm{R})$ & $192.6^{* *}$ & $116.7^{*}$ & $58.8^{* *}$ & $15.6^{* *}$ & $40.4^{* *}$ & $45.7^{* *}$ & $31.5^{* *}$ \\
\hline $40 / 60$ & 4.3 & 736.2 & 27.6 & 55.7 & 193.3 & 1.5 & 7.1 \\
\hline $75 / 25$ & 3.4 & 536.3 & 23.4 & 46.9 & 130.6 & 1.2 & 5.3 \\
\hline LSD & 0.2 & 40.3 & 1.2 & 4.7 & 20.9 & 0.1 & 0.7 \\
\hline Silicon (Si) & $53.2^{* *}$ & $60.7^{* *}$ & $15.8^{* *}$ & $9.5^{* *}$ & $13.9^{*}$ & $16.9^{* *}$ & $12.3^{* *}$ \\
\hline Absence & 3.6 & 574.2 & 24.4 & 47.9 & 152.1 & 1.2 & 5.6 \\
\hline Presence & 4.1 & 708.3 & 26.6 & 54.7 & 174.7 & 1.4 & 6.8 \\
\hline LSD & 0.2 & 40.3 & 1.2 & 4.7 & 20.9 & 0.1 & 0.7 \\
\hline $\mathrm{R} \times \mathrm{Si}$ & $7.2^{*}$ & $1.0^{\mathrm{ns}}$ & $15.8^{* *}$ & $13.7^{* *}$ & $0.1^{\mathrm{ns}}$ & $7.1^{*}$ & $0.2^{\mathrm{ns}}$ \\
\hline $\mathrm{CV}, \%$ & 3.7 & 6.5 & 4.7 & 9.7 & 13.6 & 6.9 & 11.7 \\
\hline
\end{tabular}

LSD: Least significant difference; $C V$ : coefficient of variation; ns: nonsignificant.

${ }^{*}$, "* Significant at the 0.05 and 0.01 probability levels, respectively, according to $\mathrm{F}$ test. 
Figure 4. Stem diameter (a), root length (b), root nitrogen use efficiency (c) and root dry matter (d) of yellow passionfruit seedlings under different $\mathrm{NH}_{4}{ }^{+}$and $\mathrm{NO}_{3}$ ratios with or without $\mathrm{Si}$ application.

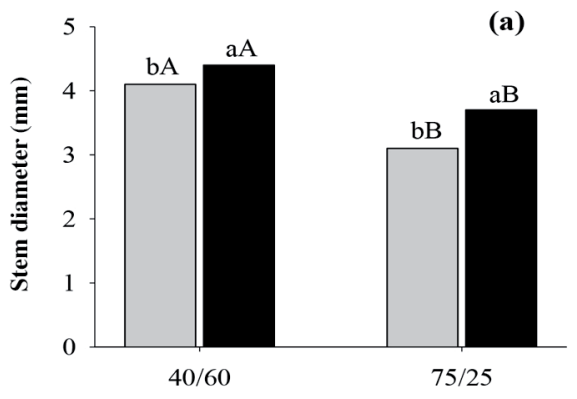

(c)

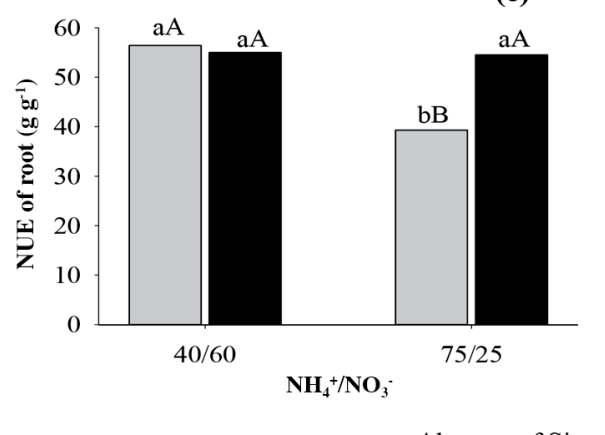

Absence of $\mathrm{Si}$

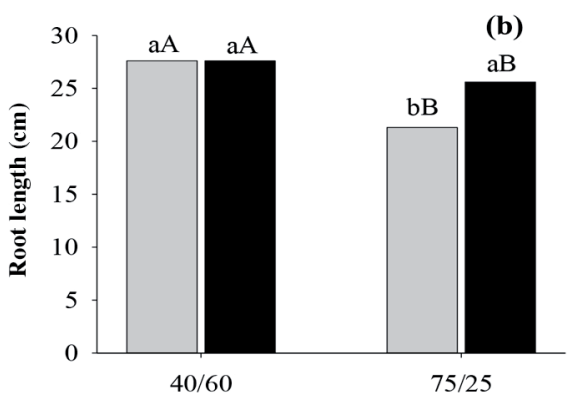

(d)

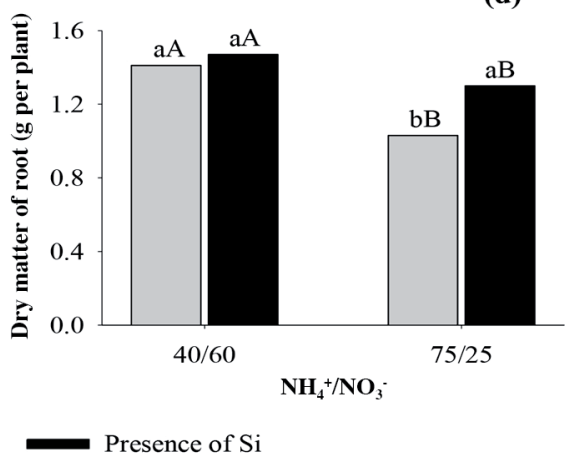

Means followed by different lower-case letters indicate $\mathrm{Si}$ significant effect within $\mathrm{NH}_{4}{ }^{+}$and $\mathrm{NO}_{3}^{-}$ratios and uppercase letters indicate $\mathrm{NH}_{4}{ }^{+}$and $\mathrm{NO}_{3}$ ratios significant effect within $\mathrm{Si}$ concentrations, according to Tukey's test $(\mathrm{P} \leq 0.05)$.

Root NUE and DM of plants cultivated under high concentration of $\mathrm{NH}_{4}^{+}$without Si application were decreased by $31.6 \%$ compared to plants with $\mathrm{Si}$ application (Figures $4 \mathrm{c}$ and $4 \mathrm{~d}$ ). High accumulation of $\mathrm{NH}_{4}{ }^{+}$in the chloroplasts may block the metabolism of glutamine synthetase-glutamate synthase (GS-GOGAT) complex and reduce NUE, as this complex is responsible for $\mathrm{N}$ uptake in plants (Bittsánszky et al., 2015). Moreover, $\mathrm{NH}_{4}{ }^{+}$toxicity decreased root NUE in plants under no application of Si due to its effect on nutrient uptake. These nutrients have physiological/structural enzymatic role in the plant that is involved on $\mathrm{N}$ conversion to $\mathrm{DM}$, as elucidated by a positive correlation between root $\mathrm{N}$ efficiency and root accumulation of $\mathrm{N}\left(\mathrm{r}=0.88^{* *}\right), \mathrm{K}\left(\mathrm{r}=0.78^{* *}\right), \mathrm{Ca}\left(\mathrm{r}=0.81^{* *}\right)$ and $\mathrm{Mg}\left(\mathrm{r}=0.76^{* *}\right)$. Therefore, decreased root NUE is associated to decreased accumulation of these nutrients.

Regardless $\mathrm{NH}_{4}{ }^{+}$and $\mathrm{NO}_{3}-$ ratios, $\mathrm{Si}$ increased leaf area, root NUE and shoot DM (Table 4). An interaction between $\mathrm{NH}_{4}{ }^{+} / \mathrm{NO}_{3}{ }^{-}$and $\mathrm{Si}$ demonstrated that under high $\mathrm{NH}_{4}{ }^{+} / \mathrm{NO}_{3}{ }^{-}$, Si enhanced stem diameter (Figure 4a), root length (Figure 4b), root NUE (Figure 4c) and root DM (Figure 4d) of yellow passionfruit seedlings. Enhanced shoot NUE due to Si application was also observed in C. arietinum (Kurdali et al., 2013), Z. mays (Campos et al., 2015), and B. oleracea (Barreto et al., 2017). It has been reported that Si supply to nutrient solution may positively affect nutrients uptake, such as N (Campos et al., 2016) and other cations (Barreto et al., 2017; Mantovani et al., 2018). Therefore, higher response in plant growth might be expected under this nutrient solution.

The beneficial effect of Si on shoot DM, regardless ammonium concentration in the nutrient solution (Table 4), is explained by its accumulation in plants. There is a positive correlation between Si shoot accumulation and shoot DM content $(\mathrm{r}=0.72 * *)$, as well as between Si root accumulation and DM content $(\mathrm{r}=0.61 * *)$. Therefore, increased shoot DM due to increased Si accumulation resulted in higher leaf area and stem diameter.

In addition, $\mathrm{Si}$ increased root DM production in seedlings of yellow passionfruit cultivated under high $\mathrm{NH}_{4}^{+}(\mathrm{Figure}$ 4d). This result might be due to Si higher accumulation in such conditions (Figure 3b) and higher root NUE (Figure 4c), elucidated by a positive correlation between root $\mathrm{Si}$ accumulation and root NUE $(r=0.80 * *)$ and root $\mathrm{Si}$ accumulation and root DM $(\mathrm{r}=0.94 * *)$. 
Therefore, Si application might be a management practice option to mitigate ammoniacal $\mathrm{N}$ toxicity in yellow passionfruit seedlings cultivation, especially in hydroponic system in which plants are prone to nutritional stresses. Further studies regarding Si role in the mitigation of ammonium toxicity in other fruit plants is necessary, since the genetic factor might be taken into consideration.

\section{CONCLUSIONS}

Silicon application in yellow passionfruit seedlings under high level of ammonium increased $\mathrm{N}$ accumulation and $\mathrm{N}$ use efficiency, root length and root DM, and leaf green color index. In addition, Si application reduced leaf electrolyte leakage index, which resulted in higher stem diameter. These results prove that silicon application mitigates ammonium toxicity in yellow passionfruit seedlings.

\section{ACKNOWLEDGEMENT}

We are grateful to the National Council for Scientific and Technological Development (CNPq) for the doctoral scholarship granted to the first author.

\section{REFERENCES}

Barreto, R.F., Cruz, F.J.R., Gaion, L.A., Prado, R.M., and Carvalho, R.F. 2018. Accompanying ions of ammonium sources and nitrate: ammonium ratios in tomato plants. Acta Agriculturae Scandinavica, Section B - Soil and Plant Science 181:1-6. doi:10.1002/jpln.201700413.

Barreto, R.F., Prado, R.M., Leal, A.J.F., Troleis, M.J.B., Silva-Junior, G.B., Monteiro, C.C., et al. 2016. Mitigation of ammonium toxicity by silicon in tomato depends on the ammonium concentration. Acta Agriculturae Scandinavica, Section B-Soil and Plant Science 66:01-08. doi:10.1080/09064710.2016.1178324.

Barreto, R.F., Schiavon-Junior, A.L., Maggio, M.A., and Prado, R.M. 2017. Silicon alleviates ammonium toxicity in cauliflower and in broccoli. Scientia Horticulturae 225:743-750. doi:10.1016/j.scienta.2017.08.014.

Bataglia, O.C., Furlani, A.M.C., Teixeira, J.P.F., Furlani, P.R., e Gallo, J.R. 1983. Métodos de análise química de plantas. Instituto Agronômico de Campinas, Campinas, São Paulo, Brasil.

Bittsánszky, A., Pilinszk, K., Gyulai, G., and Komives, T. 2015. Overcoming ammonium toxicity. Plant Science 231:184-190 doi:10.1016/j.plantsci.2014.12.005.

Campos, C.N.S., Prado, R.M., Caione, G., Lima-Neto, A.J., and Mingotte, F.L.C. 2016. Silicon and excess ammonium and nitrate in cucumber plants. African Journal of Agricultural Research 11:276-283. doi:10.5897/ajar2015.10221.

Campos, C.N.S., Prado, R.M., Roque, C.G.,Lima-Neto, A.J., Marques, L.J.P., Chaves, A.P., et al. 2015. Use of silicon in mitigating ammonium toxicity in maize plants. American Journal of Plant Sciences 6:1780-1784. doi:10.4236/ajps.2015.611178.

Chen, D., Cao, B., Qi, L., Yin, L., Wang, S., and Deng, X. 2016. Silicon-moderated K-deficiency-induced leaf chlorosis by decreasing putrescine accumulation in sorghum. Annals of Botany 118:305-315. doi:10.1093/aob/mcw111.

Choi, J.M., Latigui, H., and Lee, C.W. 2011. Growth and nutrient uptake responses of 'Seolhyang' strawberry to various ratios of ammonium to nitrate nitrogen in nutrient solution culture using inert media. African Journal of Biotechnology 10:1256712574. doi:10.5897/ajb11.1104.

Dionisio-Sese, M.L., and Tobita, S. 1998. Antioxidant responses of rice seedlings to salinity stress. Plant Science 135:1-9. doi:10.1016/S0168-9452(98)00025-9.

Fageria, N.K. 1998. Otimização da eficiência nutricional na produção das culturas. Revista Brasileira de Engenharia Agrícola e Ambiental 2:6-16. doi:10.1590/1807-1929/agriambi.v02n01p6-16.

Feng, J., Shi, Q., Wanga, X., Wei, M., Yang, F., and Xu, H. 2010. Silicon supplementation ameliorated the inhibition of photosynthesis and nitrate metabolism by cadmium $(\mathrm{Cd})$ toxicity in Cucumis sativus L. Scientia Horticulturae 123:521-530. doi:10.1016/j.scienta.2009.10.013.

Ferreira, D.F. 2011. Sisvar: a computer statistical analysis system. Ciência e Agrotecnologia 35:1039-1042. doi:10.1590/S1413-70542011000600001.

Helali, S.M., Nebli, H., Kaddour, M., Mahmoudi, H., Lachaal, M., and Ouerghi, A. 2010. Influence of nitrate-ammonium ratio on growth and nutrition of Arabidopsis thaliana. Plant and Soil 336:65-74. doi:10.1007/s11104-010-0445-8.

Hernandez-Apaolaza, L. 2014. Can silicon partially alleviate micronutrient deficiency in plants? A review. Planta 240:447-458. doi:10.1007/s00425-014-2119-x. 
Hoagland, D.R., and Arnon, D.I. 1950. The water culture method for growing plants without soils. California Agricultural Experimental Station, Berkeley, California, USA.

Hu, L., Yu, J., Liao, W., Zhang, G., Xie, J., Lv, J., et al. 2015. Moderate ammonium:nitrate alleviates low light intensity stress in mini Chinese cabbage seedling by regulating root architecture and photosynthesis. Scientia Horticulturae 186:143-153. doi:10.1016/j.scienta.2015.02.020.

Kochanová, Z., Jasková, K., Sedláková, B., and Luxová, M. 2014. Silicon improves salinity tolerance and affects ammonia assimilation in maize roots. Biologia 69:1164-1171. doi:10.2478/s11756-014-0411-7.

Kraska, J.E., and Breitenbeck, G.A. 2010. Simple, robust method for quantifying silicon in plant tissue. Communications in Soil Science and Plant Analysis 41:2075-2085. doi:10.1080/00103624.2010.498537.

Kurdali, F., Al-Chammaa, M., and Al-Ain, F. 2018. Growth and $\mathrm{N}_{2}$-fixation in saline and/or water stressed Sesbania aculeata plants in response to silicon application. Silicon 10:1-8. doi:10.1007/s12633-018-9884-2.

Kurdali, F., Al-Chammaa, M., and Mouasess, A. 2013. Growth and nitrogen fixation in silicon and/or potassium fed chickpeas grown under drought and well watered conditions. Journal of Stress Physiology and Biochemistry 9:385-406.

Li, W., Bi, Y., Ge, Y., Li, Y., Wang, J., and Wang, Y. 2012. Effects of postharvest sodium silicate treatment on pink rot disease and oxidative stress-antioxidative system in muskmelon fruit. European Food Research and Technology 234:137-145. doi:10.1007/s00217-011-1611-9.

Li, B., Li, G., Kronzucker, H.J., Baluska, F., and Shi, W. 2014. Ammonium stress in Arabidopsis: signaling, genetic loci, and physiological targets. Trends and Plant Science 19:107-114. doi:10.1016/j.tplants.2013.09.004.

Li, S., Wang, Z., and Stewart, B.A. 2013. Responses of crop plants to ammonium and nitrate. p. 205-397. In Sparks, D.L. (ed.) Advances in agronomy. Elsevier, Newark, New Jersey, USA.

Liang, Y. 1999. Effects of silicon on enzyme activity and sodium, potassium and calcium concentration in barley under salt stress. Plant and Soil 209:217-224. doi:10.1023/A:1004526604913.

Liang, Y., Sun, W., Zhu, Y.G., and Christie, P. 2007. Mechanisms of silicon-mediated alleviation of abiotic stresses in higher plants: a review. Environmental Pollution 147:422-428. doi.10.1016/j.envpol.2006.06.008.

Ma, J.F., and Yamaji, N. 2015. A cooperative system of silicon transport in plants. Trends in Plant Science 20:435-442 doi:10.1016/j.tplants.2015.04.007.

Maksimovic, J.D., Bogdanovic, J., Maksimovic, V., and Nikolic, M. 2007. Silicon modulates the metabolism and utilization of phenolic compounds in cucumber (Cucumis sativus L.) grown at excess manganese. Journal of Plant Nutrition and Soil Science 170:739-744. doi:10.1002/jpln.200700101.

Malavolta, E., Vitti, G.C., e Oliveira, S.A. 1997. Avaliação do estado nutricional das plantas: princípios e aplicações. 2a ed. Potafos, Piracicaba, São Paulo, Brasil.

Mantovani, C., Prado, R.M., and Pivetta, K.F.L. 2018. Silicon foliar application on nutrition and growth of Phalaenopsis and Dendrobium orchids. Scientia Horticulturae 241:83-92. doi:10.1016/j.scienta.2018.06.088.

Marschner, H. 2012. Mineral nutrition of higher plants. $3^{\text {rd }}$ ed. Elsevier, Oxford, UK.

Mendoza-Villarreal, R., Valdez-Aguilar, L.A., Sandoval-Rangel, A., Robledo-Torres, V., and Benavides-Mendoza, A. 2015. Tolerance of lisianthus to high ammonium levels in rockwool culture. Journal of Plant Nutrition 38:73-82. doi:10.1080/01904167.2014.920379.

Prado, R.M., Barreto, R.F., and Felisberto, G. 2017. Nitrate-ammonium ratios and silicon used in hydroponics. p. 33-56. In Webster, D.J. (ed.) Advances in hydroponics research. Nova Science Publishers, New York, USA.

Vaculíková, M., Vaculík, M., Simková, L., Fialová, I., Kochanová, Z., Sedláková, B., et al. 2014. Influence of silicon on maize roots exposed to antimony e growth and antioxidative response. Plant Physiological and Biochemistry 83:279-284. doi:10.1016/j.plaphy.2014.08.014. 